\title{
THE ROLE OF MARKET PRICE IN THE INVESTMENT VALUE THEORY*
}

A simplificatron proceeding under Section 11 of the Public Utility Holding Company Act ${ }^{1}$ is one of the settings for the ritual of corporate reorganization. ${ }^{2}$ A simplification plan must establish a capital structure for the simplified corporation on the basis of its estimated future earnings. ${ }^{3}$ And the plan normally provides for exchange of the old securities in return for cash or securities of the simplified corporation. Under the Holding Company Act the simplification plan must be "fair and equitable." ${ }^{4}$ This directive means, the Supreme Court has held, ${ }^{5}$ that the strict priority rule of the Boyd case ${ }^{6}$ is applicable. Each senior security holder must be "fully compensated" before a junior security can participate in the simplified corporation. The Supreme Court further declared in the Otis and Central Illinois cases $^{7}$ that the value of the preferred stock to be compensated under the Boyd rule was not to be measured exclusively by liquidation rights or face value. ${ }^{8}$ Instead, the Court has required that a security be compensated for its so-called investment or going concern value. ${ }^{2} \mathrm{~A}$ particular security's

* Niagara Hudson Power Corp. v. Leventritt, 19 U.S.L. WeEk 4091 (U.S. January 9, 1951).

1. 49 Stat. 803 (1935), 15 U.S.C. $\S 79(\mathrm{k})$ (Supp. 1950). This section's aim is simplification of the large utility holding company systems in line with operational optimum and geographic integration. For a full discussion of Section 11 and its legislative history, see Shaw, Public Utility Holding Company Act, Corparate Simplifications and Geographic Integration under Section 11, 36 MICE. L. REv. 1360 (1938).

2. Other settings are Chapter X, 52 STat. 883 (1938), as amended 11 U.S.C. $\S \S 501-$ 676 (1946), Chapter XI, 52 StaT. 905 (1938), 11 U.S.C. $\$ 701-99$ (1946), and Section 77, 49 Star. 911 (1935), as amended, 11 U.S.C. § 205 (1946), of the Bankruptcy Act; and Section 20(b) of the Interstate Commerce Act, 62 Stat. 162 (1948), 49 U.S.C. $§ 20 b$ (Supp. 1949).

3. Otis \& Co. v. SEC, 323 U.S. 624,630 (1944).

4. 15 U.S.C. $\$ 79(\mathrm{k})$ (e) (Supp. 1950).

5. Otis \& Co. v. SEC, 323 U.S. 624 (1944); SEC v. Central Illinois Securities Corp., 338 U.S. 96 (1949); Dodd, Preferred Shareholders Rights-The Engineers Public Service Company Case, 63 HaRv. L. REv. 298 (1949).

6. Northern Pacific Ry. v. Boyd, 228 U.S. 482 (1913). See Swaine, Reorganization of Corporations: Certain Developments of the Last Decade, 27 CoL. L. REv. 901 (1927).

7. See note 5 supra.

8. In the Otis case the Court pointed out that the reason for the inapplicability of the charter provisions ". . . does not lie in the fact that the business of the utility continues in another form. That is true of bankruptcy and equity reorganizations. It lies in the fact that Congress did not intend that its exercise of power to simplify should mature rights created without regard to the possibility of simplification of the system structure, which otherwise would only arise by voluntary action of stockholders or, involuntarily, through action of creditors." 323 U.S. $624,638$.

9. While the Otis case rejected charter liquidation preferences as a basis for asset distribution, it was not until SEC v. Central Illinois Securities Corp., 338 U.S. 96 (1949), that the Supreme Court announced the investment or going concern value theory. When securities are to be surrendered for cash, the investment value criterion is the cost of reinvestment in a security whose risk and earning expectancy are comparable to the old 
value is determined by the amount of the reasonably forseeable earnings of the corporation it would have been able to command had the corporation been allowed to continue operations. Until recently, however, it has been unclear whether a simplification plan under the Holding Company Act can eliminate a class of securities which have a market value.

In Niagara Fudson Power Corp. v. Leventritt, ${ }^{10}$ the Supreme Court, resolving a conflict between two circuits, ${ }^{11}$ upheld the elimination of perpetual stock purchase warrants despite a showing of present market value. ${ }^{12}$ In both cases the SEC had evaluated the warrant issues at zero. ${ }^{13}$ Estimating the corporations' prospective earnings, the Commission concluded that there was no reasonable expectation that the market price of the stock would

security prior to the simplification proceeding. To illustrate this the court offered the test of what a "willing buyer would pay a willing seller in today's market" (338 US 96 at 144). While this suggests use of market values as indices of going concern value it is clear from the context that the kind of market values to which the court refers are only those based on rational earning expectations. Lest there be any doubt on this score the court warns at page 146 that "the Commission would be wrong in selecting as a basis for valuation, abnormal or highly speculative market values. . . ."

For examples of the application of the investment value theory to reorganizations under $\S 20$ (b) of the Interstate Commerce Act, see Lehigh Valley RR Co. Securities Modification, 271 I.C.C. 553 (1949); Boston \& Maine RR Securities Modification, 275 I.C.C. 397 (1950).

A dictum in the Niagara decision may presage the extension of the investment value theory to reorganizations under $\S 77$ and Chapter $\mathrm{X}$ of the Bankruptcy Act. At the end of its opinion (19 U.S.L. WEEK at 4094), the Court stated: "Moreover, we find no lack of authority in analogous fields of reorganization for sustaining the general principle that a class of securities may go unrecognized in a reorganization when informed estimates of future earnings indicate that they have no investment value," citing in a footnote Group of Institutional Investors et al. v. Chicago, M., St. P. \& Pac. R.R., 318 U.S. 523 (1943) (proceeding under $\$ 77$ ), and Consolidated Rock Products Co. v. DuBois, 312 U.S. 510 (1940) (proceeding under $\$ 77 \mathrm{~B}$, the predecessor of Chapter $\mathrm{X}$ ).

10. 19 U.S. L. WEEK 4091 (U.S. January 9, 1951).

11. Niagara Hudson Power Corp. v. Leventritt, 179 F.2d 615 (2d Cir. 1949); In re Commonwealth and Southern Power Corp., 184 F.2d 81 (3rd Cir. 1950).

12. The use of perpetual warrants became fashionable during the 20 's when fixed income securities were relatively unpopular due to post-war inflation. In order to make such securities more popular they were either made convertible to common stock, or warrants to buy common were issued along with them. This package deal gave an investor speculative opportunity without the risk of actually investing in common stocks. Warrants are also used to compensate key personnel, a practice on which Congress has recently conferred special tax advantages. See $\$ 130 \mathrm{~A}$ of the Internal Revenue Code, added in the 1950 revision. When warrants are issued with securities, the set price at which the holder is entitled to purchase stock is virtually always considerably in excess of the market price when the warrants are issued. GraHam \& Dodd, Security Analysis 258-9, 554-5, 568-70 (1934). See also Garner \& Forsythe, Stock Purchase Warrants \& "Rights", 4 So. Calif. L. Rev. 269 (1930).

The motives in issuing warrants to executives may be primarily incentive and secondarily compensation. The exercise price of warrants issued to executives may be set at or very close to the stock's market price. See, generally, Baker, Stock Options for Executives, 19 Harv. Bus. Rev. 106, 112, Table I (1940).

13. SEC Holding Co. Act Release No. 9270, p. 10, 1949; id. No. 8633, p. 7, 1948. 
exceed the warrant exercise prices in the forseeable future. ${ }^{14}$ Thus the warrants would not be translated into common stock and share in corporate earnings. Put differently, this means that the equity available to the common stockholders after senior claims had been satisfied was not fully compensatory. ${ }^{15}$ Therefore no equity or value was left for the warrants. The warrant holders pointed to the fact that immediately prior to the simplification proceedings the warrants had a positive value on the market. ${ }^{16}$ This value, they argued, should be recognized by the SEC. Upon appeals

14. In the Niagara case the warrant exercise price was $\$ 42.86$ per share of stock. Since the company's formation its stock had never sold above $181 / 4$ and had sold as low as $7 / 8$. Just prior to the simplification it was about \$12. The SEC estimated foreseeable earnings at $\$ 1.39$ per share of common annually. On the liberal assumption that the common stock might sell at 15 times consolidated earnings, it would require earnings per share of $\$ 2.86$ to approximate the exercise price of $\$ 42.86$ per share. Such earnings would represent an increase of $106 \%$ over that which the SEC found reasonably foreseeable. Brief for the SEC, p. 9, In re Niagara Hudson Power Corp., 179 F.2d 615 (2d Cir. 1949).

The Commonwealth \& Southern warrants had an exercise price of \$30. The SEC earnings estimate per share was approximately $60 \mathrm{c}$. At this rate it would require capitalization of the common at 50 times consolidated earnings in order to attain a market value of $\$ 30$. And in order to attain a price of $\$ 30$ when capitalized at 15 (a liberal capitalization rate) the increase in estimated earnings would have to be roughly $233 \%$. Cf. Brief for the SEC, p. 5, In re Commonwealth \& Southern Corp., 184 F.2d 81 (3rd Cir. 1950). Not only was there an economic unlikelihood of such earnings, but the Commission in both cases pointed to the fact that were such earnings actually being made state regulatory commissions would certainly reduce them by ordering a reduction in rates.

15. Doctrinally, the decision that a class of securities be eliminated because of no possibility of participating in future earnings is the same as the decision that the class immediately superior to it has not been fully compensated. Practically, it may make a difference from which end the Commission starts its decision-making process. For example, in Otis \& Co. v. SEC, 323 U.S. 624 (1944), the procedure followed was to decide that the common stock was entitled to something, that a fair share for them was $5 \%$ of the new common, and that therefore the preferred would be fully compensated by receiving the remaining 95\%. A different result, at least as to the amount received by common, if not as to the decision whether they should get anything, might have been reached if the SEC had first attempted to determine how much the preferred should receive in order to be fully compensated for each stick in their "bundle of rights," and then simply given what was left to common. See also Boston \& Maine RR Securities Modification, 275 I.C.C. 379 (1950), under $\S 20$ (b) of the Interstate Commerce Act, where the ICC used both approaches in the same case.

16. Perpetual options will always have a market value in excess of zero as long as a spark of life remains in the corporation. The operations of any corporation no matter what its present condition may become profitable at some time in the future. Such a hope will always be given a value on the market. See BERLE \& MEANS, The MOdERN Corforation AND Private PRoperty 183 (1932).

The Niagara warrants prior to the simplification were selling for about $\$ 3$ and the common stock at $\$ 16$. Brief for Respondent, p. 38, Niagara Hudson Power Corp. v. Leventritt, 19 U.S.L. WeEK 4091 (U.S. Jan. 9, 1951).

The Commonwealth warrants sold at $x / 2$ with a common stock price of about $43 / 8$. Brief of Appellant, p. 21, In re Commonwealth \& Southern Power Corp., 184 F.2d 86 (3rd Cir. 1950). 
the third circuit in one case agreed with the SEC, ${ }^{17}$ the second circuit in the other case with the warrants holders. ${ }^{18}$ In a 6 to 2 decision, the Supreme Court reversed the second circuit.

Narrowly construed, the Supreme Court's holding is limited to situations in which the SEC eliminates entirely a class of securities with present market value. But the Court's reasoning is equally applicable to a situation in which the Commission's finding of investment value, while greater than zero, varies substantially from market price. For the Court felt that "the informed judgment of the Commission, rather than that of the market" is the appropriate guide to the meaning of "fair and equitable" under the Act, and that the Commission is not bound "to limit itself precisely to the values which the market recognizes." 19

As the Court realized, to regard market price as the sole index of going concern value gives more weight to market price than seems justified. In the Niagara case, for example, intelligent application of the reasonably forseeable earnings test to determine going concern value would require computations too intricate and intangible for the warrant purchaser to make. The basic determinant of a warrant's investment value is an appraisal of the chances of the underlying stock's future appreciation. ${ }^{20}$ This, of course, hinges largely on a determination of the utility's profit-making ability. And such a determination requires matching estimated gross income against current and anticipated obligations and expenses. Area potential, the growth of the national economy, future price tendencies, the impact of atomic energy, and utility regulation policies are among the additional applicable considerations. ${ }^{21}$

Apart from earning power of the utility, appraisal of the underlying stock's appreciation potential depends on the amount of dividends it can expect. Here, consideration must be given to the potential dilutionary effect on future profits created by warrants. A warrant when exercised and transformed into stock immediately begins to participate in profits. But the capital increment created by its exercise may not add to earnings for some time. Since this dilution of earnings will act to retard future advances in stock, any intelligent estimate of the stock's value must take into account the number of warrants outstanding. ${ }^{22}$ In view of the difficulty inherent in these computations it seems clear that the SEC is better equipped and in a better position than warrant buyers to make an estimate of warrant values. ${ }^{23}$

17. 184 F.2d 81 (3rd Cir. 1950).

18. 179 F.2d 615 (2d Cir. 1949).

19. 19 U.S. L. WeEK 4093 (U.S. January 9, 1950).

20. BERLE \& MEANS, op. cit. supra note 16, at 184 n.54.

21. For a detailed exposition of factors considered in an SEC evaluation, see SEC Holding Co. Act Release No. 8889, 1949.

22. For a discussion of whether this dilution takes place when warrants are issued or when they are exercised, see BERIE \& MEANS, op. cit. supra note 16, at $184 \mathrm{n} .55$.

23. The SEC is under a positive duty to make an independent evaluation. Under $\S 24$ of the Holding Company Act, its findings of fact are conclusive if supported by sub- 
Actually it is doubtful if warrant buyers even attempt such an estimate. ${ }^{24}$ In the Niagara and Commonwealth \& Southern cases, the market was probably gambling in part on the outcome of the simplification proceedings themselves. More important, it was evaluating the warrant holder's chance to share in unanticipated earnings. One of the elements of the value of common stock is the hope that the market's own prediction of a company's profits is too pessimistic $c_{y}$ that unforseen events will bring large gains to the common stockholders. ${ }^{25}$ And warrant holders were paying for a chance at these speculative earnings. ${ }^{26}$ The chance may have real value. But since it is not based on reasonably forseeable earnings it is not a compensable value under the Public Utility Holding Company Act. ${ }^{27}$

It is true that market cash values running into millions of dollars are destroyed by the SEC plan. ${ }^{28}$ However, the investment value approach rests on a Congressional policy that the administration of the Act should

stantial evidence. 49 STaT. 834 (1935), 15 U.S.C. $\$ 79(x)$ (Supp. 1950). For a discussion of the scope of judicial review under this portion of the Act, see Note, 43 IrL. L. REv. 882 (1949).

Evaluation techniques and procedures used are set forth in SEC Holding Co. Act Releases No. 6083, 1945 and No. 9270, 1949.

24. The SEC urged in argument: "Indeed, we question altogether whether those who bought and sold option warrants were even attempting to register their appraisal of the intrinsic advantages of being able to exercise the warrants at any future time. We believe it more likely that many of them were gambling on future short term gyrations in the market -as to what other gamblers might pay in the hope of reselling to other gamblers." Brief for the SEC, p. 16, 179 F.2d 615 (2d Cir. 1949).

A striking example of this sort of activity in apparently worthless securities is available daily on the New York Foreign Bond curb market where Czarist Russian Bonds issued in 1919 and 1921 are traded actively. See, e.g., N.Y. Herald Tribune, January 13, 1951, p. 20.

25. As the Court pointed out, "The value of this 'perpetual feature' may be called the premium value of the warrants as distinguished from their investment value. It takes into account such possibilities as that of a runaway inflation, an unprecedented accumulation of undistributed surplus earnings, an unlikely liberalization of standards of public utility regulation, a surprise discovery of oil on company property, etc." 19 U.S.L. WEEK at 4093.

26. Actually, warrant holders might not be interested in sharing in earnings at all. While perpetual warrant issues are rare and experience with them limited, there is strong indication that they may never be exercised. This is because the low carrying cost of the long position they represent gives them a trading value which stays slightly ahead of the gains to be realized by exercising them. Thus, no matter how high the price of the underlying stock might go it would be more profitable for the warrant holder to sell the warrant than to exercise it. Since there is no actual dilution of the stockholders' interests until the warrant is exercised there may never be a dilution at all where perpetual warrants are involved. Berle \& Means, op. cit. supra note 16, at 183. See also Huebner, The Stock MARKET (1922).

27. For a case in which perpetual warrants were given a positive value in a simplification similar to the Niagara case, see Electric Power and Light Corp., SEC Holding Co. Act Release No. 8889, pp. 70-74, 1949, affirmed, 176 F.2d 687, 691 (2d Cir. 1949).

28. In the Commonwealth \& Southern case this value was set at $\$ 12,750,000$ by the appellant. Brief of Appellant, p. 18, In re Commonwealth \& Southern Power Corp., 184 F.2d 86 (3rd Cir. 1950). In the Niagara case the figure was $\$ 1,500,000$. Brief for respondent, p. 38, Niagara Hudson Power Corp. v. Leventritt, 19 U.S.L. WEEK 4091 (U.S. Jan. 9, 1951). 
not unduly disturb investment values. ${ }^{29}$ This policy could hardly require recognition of valueless interests in plans, which would result either in creating an inflated capital structure for the new corporation, or in affording senior interests less than their full compensation. Undoubtedly warrant holders had well considered reasons for purchasing them. But the only possible part of that decision to buy which offers a valid basis for sympathy is the hope of directly sharing in reasonably forseeable earnings of the corporation. If that hope existed at all it was clearly so speculative that it would be grossly unfair to evaluate it at the expense of the common stockholders. The SEC determination, as affirmed by the Court, is merely a familiar aspect of business life in action-part of the price of speculation is the risk of total loss.

29. "Simplification and reorganization of holding-company structures, making possible within a reasonable period the practical elimination of the holding company, should be conducted under the Commission's supervision over a period of time to prevent undue losses to security holders from investment dislocations." S. REP. No. 621, 74th Cong., 1st Sess. 60 (1935). And see note 5 supra. 